\title{
Biomolecular Characterization of Bacillus tequilensis A1C1 Isolated from Soil and Chromatographic Analysis of D-serine in its Cellular Fraction
}

\section{Shikha Kapil}

Chandigarh University

Monika Bhattu

Chandigarh University

\section{Tarun Kumar}

Chandigarh University

Vipasha Sharma ( $\sim$ sharma.vipasha@gmail.com)

Chandigarh University https://orcid.org/0000-0001-6903-0513

\section{Research Article}

Keywords: Bacillus tequilensis, D-amino acids, serine enantiomers, antibacterial activity

Posted Date: October 4th, 2021

DOI: https://doi.org/10.21203/rs.3.rs-935178/v3

License: (c) (1) This work is licensed under a Creative Commons Attribution 4.0 International License.

Read Full License 


\section{Abstract}

The bacteria isolated from the pomace dumping soil site (bacteria id $\mathrm{A} 1 \mathrm{C} 1$ ) showed maximum growth $\left(0 . D_{600}=1.97 \pm 0.4 \times 10^{9}\right.$ cells $\left./ \mathrm{ml}\right)$ within $48 \mathrm{~h}$ in the minimal salt media supplemented with L-serine. The isolated strain was identified as 'Bacillus tequilensis' through 16sRNA sequencing. The strain was quantified for D-serine content by using RP-HPLC. The D-serine concentration was calculated as $0.919 \pm 0.02 \mathrm{nM}$ in the bacterial cellular fraction by using a standard curve plot and linear curve equation. Further, recovery \% was also calculated for the spiked samples which vary from $85-90 \%$. The study's peculiarity reflects the fact that the isolated strain was explored for the first time to detect the presence of serine enantiomers. The biochemical features also showed $70 \%$ similarity to the standard strain Bacillus tequilensis $10 \mathrm{~b}^{\top}$. The optimum growth parameters were recorded as $37^{\circ} \mathrm{C} \pm 0.5,150 \pm 0.5 \mathrm{RPM}$, and $7 \pm 0.5 \mathrm{pH}$. The strain was Gram-positive and synthesized endospores. Morphological results showed its rod shape, large, irregular, and off-white-coloured colonies. A1C1 was also tested for the production of secondary metabolites and enzymes. A1C1 showed positive results for indole production, lactose fermentation, protease, and gelatinase whereas, negative results for catalase, MR-VP, citrate utilization, cellulase, amylase, and pectinase. Further, the strain was assayed for PGPR attributes and showed a negative phosphate solubilization index and IAA production. The antibacterial assay showed $5 \%$ and $2 \%$ efficacy of the extracellular fraction against MTCC 40 and MTCC 11949 respectively. These results demonstrate that Bacillus tequilensis $\mathrm{A} 1 \mathrm{C} 1$ has antibacterial activity, the potential to secrete extracellular enzymes, and D-serine content in the intracellular fraction of the cultivated cells.

\section{Key Points}

- Isolated strain is identified as Bacillus tequilensis A1C1.

- The strain can secrete extracellular enzymes and has antibacterial activity against MTCC 40 and MTCC 11949.

- The concentration of D-serine in the bacterial intracellular fraction is $0.919 \pm 0.02 \mathrm{nM}$.

\section{Introduction}

In the past years, the scientific fraternity has been attracted to D-serine due to its significant role in mammals [1,2]. D-serine is a well-studied and recognized regulator of various activities in the human nervous system $[3,4]$. In the brain, D-serine is known as a co-agonist of the primary $N$-methyl D-aspartate (NMDAr) receptor, which upon binding to it effectuates NMDAr mediated signaling between nerve cells [5, 6]. Moreover, their important role has also been witnessed in shaping synaptic plasticity [7]. D-serine levels above or below the scale have been documented to contribute to causing neurological complications [8]. In plants, D-serine acts as an effective agonist of glutamate receptors, which function to control the nitrogen cycle and growth of pollen tubes [9]. 
Moreover, in a terrestrial environment, $3-7 \%$ of total serine is present in soil [10], $5-10 \%$ of total serine in rivers [11], and $4 \%$ of total serine in lakes [12]. Few bacterial strains are reported to synthesize Dserine, for instance, vancomycin-resistant Enterococcus gallinarum BM4174 [13], marine heterotrophs: Cytophaga sp. IRII13, Erythrobacter longus, Roseobacter litoralis, Pseudoaltermonas piscidia, freshwater heterotrophs: Acidovorax sp., Comamonas sp., Cytophaga sp. [14] and anaerobic archaeon hyperthermophilic: Pyrobaculum islandicum, methanogenic: Methanosarcina barkeri, hyperhalophilic: Halobacterium salinarium [15], purple bacteria such as Paracoccus denitrificans, Pseudomonas aeruginosa, and Escherichia coli [16]. Interestingly, serine diastereomers are also reported to be present in antimicrobial peptides [17], siderophores [18], bacterial lipopeptide biosurfactants [19, 20], and bacterial peptidoglycan (PG) [21].

D-serine has biological importance and its biosynthetic pathway has been greatly studied. Serine racemase (SR, EC.5.1.1.18) is a multifunctional, pyridoxal 5-phosphate (PLP) dependent enzyme responsible for the synthesis of $D$-serine from $L$-serine through racemization $[22,23]$. SRs genes have been found in both prokaryotes and eukaryotes and are being investigated for their enzymatic properties/activities [24]. Howbeit, our knowledge in the case of prokaryotic SRs is still constrained. For instance, the synthesis of D-serine in marine heterotrophs is unstable and inhibits the bacterial growth of Roseobacter litoralis Och 149 [25]. In Enterococcus gallinarum BM4174, Alanine racemase is known to synthesize D-serine which is the further precursor of PG of this Gram-positive bacteria [13]. Peptidelinkages in Gram-positive bacteria PG vary considerably and are not confined to D-glutamate and Dalanine as they are in Gram-negative strains, but also include D-serine, D-aspartate, and D-ornithine [26]. Some Gram-positive Bacillus is also reported to produce D-serine in their lipopeptide biosurfactants [19, 20].

In the present study, while investigating the distribution of serine enantiomers in bacterial strains, "Bacillus tequilensis" is found to possess D-serine in its various cellular fractions. Previously, Bacillus tequilensis strains have been shown to synthesize lipopeptide biosurfactants [27], possess fibrinolytic activity [28], antifungal activity against Magnaporthe oryzae [29], pectinase activity [30], and alkaline protease activity [31]. Albeit, the potential of D-serine synthesis has not been reported in the Bacillus tequilensis strains. This is the first-ever report of the exploration of "Bacillus tequilensis" in the context of serine diastereomers.

\section{Material And Methodology}

\section{Site description and sample collection}

Soil samples were collected from the native land of North India covering Himachal Pradesh (H.P), Punjab, and Jammu \& Kashmir (J\&K) during the period of July-October 2018. From each zonal area, various districts were explored for the selection of soil samples (Table S1) used in the given study. Soil samples were collected from the mountainous-zone of Himachal Pradesh district Bilaspur (31 ${ }^{\circ} 46^{\prime 2} 25.02^{\prime \prime} \mathrm{N}$ $\left.76^{\circ} 78^{\prime} 55.34^{\prime \prime} \mathrm{E}\right)$ temperature ranges from $28.4 \pm 2^{\circ} \mathrm{F}(\mathrm{min})$ to $113^{\circ} \mathrm{F} \pm 2^{\circ} \mathrm{F}(\max )$, district Hamirpur 
$\left(31^{\circ} 37^{\prime} 27.14^{\prime \prime} \mathrm{N} 76^{\circ} 34^{\prime} 9.25^{\prime \prime} \mathrm{E}\right.$ ) temperature ranges from $33.8 \pm 2^{\circ} \mathrm{F}(\mathrm{min})$ to $116 \pm 2^{\circ} \mathrm{F}$ (max) and district Solan $\left(30^{\circ} 50^{\prime} 13.79^{\prime \prime} \mathrm{N} 76^{\circ} 57^{\prime} 41.13^{\prime \prime} \mathrm{E}\right)$ temperature ranges from $25.5 \pm 2^{\circ} \mathrm{F}(\mathrm{min})$ to $102.2 \pm 2^{\circ} \mathrm{F}$ (max) of Himachal Pradesh, India. From the sub-tropical climate of Jammu \& Kashmir district Srinagar $\left(34^{\circ} 5^{\prime} 1.17^{\prime \prime}\right.$ $\left.\mathrm{N} 74^{\circ} 47^{\prime} 50.53^{\prime \prime} \mathrm{E}\right)$ temperature ranges from $-4 \pm 2^{\circ} \mathrm{F}(\mathrm{min})$ to $103.1 \pm 2^{\circ} \mathrm{F}(\max )$ and district Mohali $\left(30^{\circ} 42^{\prime} 16.73^{\prime \prime} N 76^{\circ} 43^{\prime} 4.34^{\prime \prime} \mathrm{E}\right.$ ) of Punjab, India, temperature ranges from $34 \pm 2^{\circ} \mathrm{F}$ (min) to $117 \pm 2^{\circ} \mathrm{F}$ ( $\max$ ). Soil samples were collected from the rhizosphere region from the depth of $15 \mathrm{~cm}$ in a sterile sample collecting vials and preserved at $4^{\circ} \mathrm{C}$ until use.

\section{Isolation and screening of bacterial isolates}

Each soil sample was serially diluted with autoclaved water under sterile conditions using laminar airflow. The dilution containing $10^{6}$ colonies forming units (CFU) per gram of soil was used to spread on plates containing M9 minimal salts media plates and incubated at $37^{\circ} \mathrm{C}$ for $24 \mathrm{~h}$. Primary screening was done by using M9 minimal salts media containing $0.5 \% \mathrm{~L}$-serine as a sole nitrogen source. $\mathrm{M} 9$ minimal salts media (1 litre) was prepared with $\mathrm{KH}_{2} \mathrm{PO}_{4}, 2.44 \mathrm{~g} ; \mathrm{Na}_{2} \mathrm{HPO}_{4}, 5.57 \mathrm{~g} ; \mathrm{Na}_{2} \mathrm{SO}_{4}, 2 \mathrm{~g} ; \mathrm{KCl}, 2 \mathrm{~g} ; \mathrm{NH}_{4} \mathrm{Cl}, 5 \mathrm{~g} ; \mathrm{NaCl}$, $1 \mathrm{~g} ; \mathrm{MgCl}_{2}, 0.2 \mathrm{~g} ; \mathrm{FeCl}_{3}, 0.001 \mathrm{~g} ; \mathrm{CaCl}_{2}, 0.003 \mathrm{~g} ; \mathrm{MnCl}_{2}, 0.02 \mathrm{~g} ; 0.5 \%$ Glucose, $0.5 \%$ L-serine and sterilized by autoclaving with $15 \mathrm{lb}$ pressure at $121^{\circ} \mathrm{C}$ for $10 \mathrm{~min}$ to avoid caramelization of glucose. All the chemicals were lab-grade purchased from HiMedia Laboratories LLC. The secondary screening was done to pick up the potent strain showing maximum growth on the M9 minimal salts media by using L-serine and PLP. A positive culture was selected and repeatedly streaked on a nutrient agar plate to obtain single and pure culture and preserved at $4^{\circ} \mathrm{C}$ for future use.

\section{Hemolysis of blood cells}

A Biosafety of the isolated strain was confirmed on a blood agar medium containing human blood $5 \%$ $\mathrm{v} / \mathrm{v}$. Dilution containing $10^{6} \mathrm{CFU}$ of fresh culture was swab aseptically on the blood agar plate and incubated at $37^{\circ} \mathrm{C}$ for $48 \mathrm{~h}$. Hemolysis of red blood cells was observed to ensure the biosafety level of the isolated strain.

\section{Molecular, biochemical, and morphological identification}

The morphological features of the culture strain were examined on a nutrient agar medium. Another biochemical and physiological characterization was carried out in compliance with Bergey's Manual of Systematic Bacteriology [32]. For molecular characterization, a PCR was conducted to amplify the $16 \mathrm{~S}$ rRNA gene from the genomic DNA extracted from the culture strain and compared with the existing $16 \mathrm{~S}$ rRNA sequences from an online database NCBI using BLASTn [33]. Further, the evolutionary analysis and phylogenetic tree were constructed using BLAST software by using the Maximum Likelihood method. The acquired nucleotide sequence was deposited into the GenBank database under an accession number.

\section{Determination of enzymes and metabolites}


The isolated culture strain was tested for the production of chitinase described elsewhere [34], cellulase, protease, and IAA production [35], gelatinase production (Bose et al., 2014). The antibacterial potential of the isolated strain was evaluated by using Agar well diffusion method. MHA (Mueller Hinton Agar) was used as a supporting culture medium for test organisms [37]. Freshly overnight incubated MTCC 11949 and MTCC 40 bacterial cultures were used as test organisms for the assay (O.D $\leq 0.1$ at $600 \mathrm{~nm}$ ). Antibiotic (Penicillin-10mcg and Ampicillin-10mcg) was used as a positive control in the assay and zone of inhibition was measured in $\mathrm{mm}$. The MHA plate was inoculated by using a sterile cotton swab to spread desired amount (100ul) of the test organism (O.D $\leq 0.1$ at $600 \mathrm{~nm})$ across the entire agar surface. Then, using a cork borer or an auto-pipette tip $(1 \mathrm{ml})$, a well with a diameter of 6-8mm was aseptically punched. Aseptically, desired amount (200ul) of the test sample was introduced into the well. For antimicrobial activity, two cellular fractions were synthesized. Then, carefully transfer the assay plates into an incubator $\left(37^{\circ} \mathrm{C}\right)$ and observe after the overnight incubation period. The test sample diffuses in the agar medium and inhibits the growth of the test organism which was measured in terms of zone of inhibition.

Cellular fractions - Initially, overnight incubated culture media was centrifuged at 10,000 RPM for 10min at $4^{\circ} \mathrm{C}$. The supernatant was collected and labeled as an extracellular fraction. The pellet obtained from the previous step was washed twice with 1X PBS buffer ( $\mathrm{pH}$ 7.4) and centrifuged to remove any media residues. Then obtained pellet was sonicated (Labman probe sonicator) after mixing with 500uL of lysis buffer (100 mM Tris HCL, $150 \mathrm{mM} \mathrm{NaCl} \mathrm{pH-8.0).} \mathrm{Then} \mathrm{cell} \mathrm{lysate} \mathrm{was} \mathrm{centrifuged} \mathrm{at} \mathrm{15,000} \mathrm{RPM} \mathrm{for}$ $15 \mathrm{~min}$ at $4{ }^{\circ} \mathrm{C}$. From the homogenate, the supernatant was collected and labeled as an intracellular fraction.

\section{Chromatographic analysis of the enantiomers}

Sample preparation- For D-amino acid (D-AAs) determination, both the cellular fractions (the detailed methodology is given in the "Determination of enzymes and metabolites" section) were separately dried in the centrifugal evaporator, suspended in $6 \mathrm{M} \mathrm{HCL}$, and hydrolyzed for $20 \mathrm{~h}$ at $100^{\circ} \mathrm{C}$ in storage vials with screw caps, to liberate amino acids [38]. Then cellular fractions were immediately placed into cool water to terminate hydrolysis and centrifuged to remove any precipitates formed during hydrolysis.

TLC-Thin layer chromatography (TLC) was performed on an aluminum TLC Silica gel $60 \mathrm{~F}_{254}(20 \mathrm{X}$ $20 \mathrm{~cm}$, Merck, Darmstadt, Germany) plate. TLC plates were pre-activated at $110^{\circ} \mathrm{C}$ for 5 min before application. A 30 ul portion of the sample was applied to the TLC plates. The plates were developed in potassium dihydrogen phosphate buffer $(40 \mathrm{mM}, \mathrm{pH}-12)$-methanol-acetonitrile $(20: 70: 10 \mathrm{v} / \mathrm{v})$ at room temperature. Then plates were dried and kept at $110^{\circ} \mathrm{C}$ for $5 \mathrm{~min}$ for post-developmental treatment. $0.2 \%$ ninhydrin in acetone was used as a visualizing agent. The colored spot was scraped off the TLC plate and extracted with methanol-water $(1: 1, \mathrm{v} / \mathrm{v})$, and dried in a vacuum evaporator for further analyses in HPLC. $R_{F}$ value of the separated spots was calculated by using L-serine as a reference compound and the given formula: 


\section{$R f=\frac{\text { Distance travelled by sample }}{\text { Distance travelled by solvent }}$}

RP-HPLC For the HPLC analysis, reverse-phase C-18 column (Agilent, C-18, $250 \mathrm{X} 4.6 \mathrm{~mm}, 5 \mathrm{um}$ ) and Agilent (1220 Infinity II LC) HPLC system. Gradient elution was applied as described elsewhere with further modifications [25]. The solvent system was set as: A. sodium acetate ( $\mathrm{pH} 6.5,40 \mathrm{mM})$; $\mathrm{B}$. methanol: acetonitrile (30:70). The programme was set as follows: $10 \%$ B for $10 \mathrm{~min} ; 10 \%-35 \%$ B for 10 $\mathrm{min} ; 35 \% \mathrm{~B}$ for $10 \mathrm{~min} ; 35 \%-60 \%$ B for $10 \mathrm{~min} ; 60 \%$ B for $10 \mathrm{~min}$. Total run time was set for $40 \mathrm{~min}$ at the flow rate of $1.0 \mathrm{ml} / \mathrm{min}$. The amount of $\mathrm{D}$-and L-enantiomers of amino acids was analysed based upon the peak area obtained after the HPLC run. A known concentration of derivatized L- and D-serine were used as calibration standards. For derivatization, into $30 \mu \mathrm{L}$ of sample $20 \mu \mathrm{L}$ of OPA/IBLC derivatizing agent was added to form diastereomers [39]. All the chemicals used were of chromatographic grade purchased from HiMedia Laboratories LLC.

\section{Statistical analysis}

The experiment was repeated three times and $p<0.05$ was considered as the statistical significance of the data. PRISM version 5.02 was used to draw graphs. Two-way ANOVA was used to calculate the Mean \pm SD of three independent values.

\section{Results}

\section{Isolation and screening of bacterial isolates}

Initially, D-serine-producing microbes were isolated on an M9 minimal salt medium containing L-serine as a nitrogen source. In Total 9 potent different colonies (given as b-Ca2C3, c-Rm2C2, d-Rm2C3, e-A1C1, fA1C2, g-Ca1C1, h-Ca1C2, i- G1, j-K1) (Fig S1) were isolated from different sites (Table S1) in the period between August 2018-October 2018. The average high/low temperature was recorded for Bilaspur $100^{\circ} \mathrm{F} / 75.2^{\circ} \mathrm{F}$, Hamirpur $98.6^{\circ} \mathrm{F} / 75.2^{\circ} \mathrm{F}$, Solan $69.8^{\circ} \mathrm{F} / 62.6^{\circ} \mathrm{F}$, Mohali $93.2^{\circ} \mathrm{F} / 75.2^{\circ} \mathrm{F}$, Srinagar $86^{\circ} \mathrm{F} / 48.2^{\circ} \mathrm{F}$. Among, all the isolates $\mathrm{A} 1 \mathrm{C} 1$ showed maximum activity $\left(\mathrm{O} \mathrm{D}_{600}-1.97 \pm 0.4 \times 10^{9} \mathrm{cells} / \mathrm{ml}\right)$ even after $48 \mathrm{~h}$ of incubation at $37 \pm 0.5^{\circ} \mathrm{C}$ (Fig.1). The assay was performed in triplicates $(n=3)$.

\section{Hemolysis of blood cells}

The pathogenic behavior of the isolated strain was performed on the test medium supplemented with human blood $5 \% \mathrm{v} / \mathrm{v}$ and confirmed by the hemolysis of RBCs. Bacterial isolate was observed for 5 days of incubation at $37 \pm 0.5^{\circ} \mathrm{C}$. No significant changes were observed during the incubation time.

\section{Molecular, biochemical, and morphological identification}


The 16s rRNA sequence analysis of the isolate A1C1 confirmed its close relationship to Bacillus tequilensis. BLAST analysis was conducted for a sequence of $1400 \mathrm{bp}$ length which showed a $99.93 \%$ similarity index to Bacillus tequilensis KCTC 13622(T) (accession no. AYT001000043). The next closest homolog was Bacillus cabrales TE3(T) (accession no. MK462260) similarity index $99.86 \%$ and Bacillus inaquosorum KCTC 13429(T) (accession no. AMXN01000021) similarity index 99.86\% (Table S2). To infer the evolutionary relationship between nearby homologs, a phylogenetic tree was also constructed which showed the sister descendant i.e., Bacillus tequilensis KCTC 13622(T) (accession no. AYT001000043) Fig. 2.

Biochemical and physiological properties of $\mathrm{A} 1 \mathrm{C} 1$ isolated from the soil of a pomace dumping site in Solan, H.P were also identified and summarised in Table 1. The temperature assay showed growth of the isolated bacteria on a temperature range from $20-50^{\circ} \mathrm{C}$ and optimum growth observed at $30-40^{\circ} \mathrm{C}$. The $\mathrm{pH}$ assay showed growth ranges from 4-10pH and optimum growth observed at 6-7pH, at $150 \mathrm{RPM}$. The isolated strain was recorded positive for the triple sugar iron test but no black precipitate was observed. A1C1 was found motile and able to ferment lactose, indole production, and grow in MRS broth. A1C1 was reported negative for starch hydrolysis, urease production, MR-VP test, citrate utilization, and cellulose hydrolysis. The isolated strain was also compared with standard strain and other reported Bacillus tequilensis strains. $\mathrm{A} 1 \mathrm{C} 1$ showed maximum similarity to the standard strain Bacillus tequilensis $10 \mathrm{~b}^{\top}$.

Morphological characteristics of A1C1 are shown in Fig.3. The isolated strain was Gram-positive and tend to form spores. A1C1 was also viewed under Scanning electron microscopy (SEM) and observed as columnar. The cultured colonies were large, spreading, and irregular in shape. Combined with all the morphological, biochemical, and molecular characterization, A1C1 was designated as Bacillus tequilensis. In addition, 16S rRNA partial sequence was submitted to the GenBank with accession no. MZ337537 as Bacillus tequilensis A1C1 (Bacillus tequilensis strain A1C1 16S ribosomal RNA gene, partial sequence - Nucleotide - NCBI (nih.gov)).

\section{Determination of enzymes and metabolites}

The isolated strain showed hydrolysis in selected mediums depicted in Fig. 4. The hydrolyzing potential of the strain was observed for up to 5 days at $37 \pm 0.5^{\circ} \mathrm{C}$. $\mathrm{A} 1 \mathrm{C} 1$ was growing well on all the mediums but displayed a clear zone of hydrolysis surrounding the colony only in protease and gelatine medium. Which indicated $\mathrm{A} 1 \mathrm{C} 1$ could secrete proteolytic and gelatine hydrolyzing enzymes. A zone of hydrolysis has appeared after $14 \mathrm{~h}$ of incubation at $37 \pm 0.5^{\circ} \mathrm{C}$. $\mathrm{A} 1 \mathrm{C} 1$ was unable to hydrolyze cellulose, pectin, phosphate, and IAA production.

Active secondary metabolites and cell wall degrading enzymes are present in many biological control agents. As a result, the isolated strain was also investigated for its potential to be used in the synthesis of antimicrobial agents. Bacterial cellular fractions were used to evaluate the antimicrobial potential of $\mathrm{A} 1 \mathrm{C} 1$. The extracellular fraction was found to be more active against MTCC $40(4.6 \pm 0.5 \mathrm{~mm})$ 
and MTCC $11949(2.3 \pm 0.5 \mathrm{~mm})$ as compared to the intracellular fraction and is summarised in Table S3. The zone of inhibition of both the fraction is shown in Fig 5 .

The zone of inhibition was observed 5mm against Escherichia coli (MTCC 40). The zone of inhibition was observed $2 \mathrm{~mm}$ against Staphylococcus aureus (MTCC 11949). Further, from the visible clear zone, the sample was taken and streaked on another agar plate which showed that the extracellular fraction had bacteriostatic activity. Efficacy of the extracellular fraction was also compared with the standards and values enumerated in percentage (\%). From the experiment, it was observed that against MTCC 40, the efficacy values of the test samples were given as $18 \%$ for ampicillin, $17 \%$ for penicillin, and $5 \%$ for the bacterial extracellular fraction. For MTCC 11949, the efficacy values of the test samples were given as $15 \%$ for ampicillin, $14 \%$ for penicillin, and $2 \%$ for a bacterial extracellular fraction.

\section{Chromatographic analysis of the enantiomers}

The method described here for TLC was applied successfully to separate the amino acids present in both the cellular fractions. The coloured spots obtained after spraying ninhydrin solution and the $\mathrm{R}_{\mathrm{F}}$ value of each spot are calculated and shown in Fig 6 . The solvent system was designed carefully to maintain the $\mathrm{pH}$ and to separate polar amino acids. For TLC, L-serine was used as the reference standard and developed a purple-pink chromatographic band with $R_{F}$ value $0.51 \pm 0.015$.

The intracellular fraction was separated into three different chromatographic bands $b 1\left(R_{f}\right.$ $-0.55 \pm 0.005), b 2\left(R_{f}-0.62 \pm 0.010\right)$, and $b 3\left(R_{f}-0.73 \pm 0.017\right)$. The extracellular fraction was separated into three chromatographic bands $c 1\left(R_{f}-0.48 \pm 0.015\right), c 2\left(R_{f}-0.62 \pm 0.005\right)$, and c3 $\left(R_{f}-0.65 \pm 0.011\right)$.

Chromatographic bands $b 1$ and $c 1$ showed $R_{f}$ values near to the standard I-serine chromatographic band. For HPLC analysis methodology described by Kubota et al., 2016 was adopted and used after modifications insolvent system. The obtained chromatograms were shown in Fig. 7.

Under the optimal reaction conditions, a linear calibration curve (peak area versus concentration) (Fig. 8) was obtained over a concentration range of $5 \mathrm{nM}$ to $30 \mathrm{nM}$ (Table S4) of the standard D-Serine containing $5,10,20,30 \mathrm{nM}$. The correlation coefficient was found to be 0.9895 . The standards for the linearity curve were prepared by adding the derivatizing agent to the std. the solution as discussed above in methodology.

The bacterial sample was analyzed using the above-mentioned HPLC method. The quantification of the target analyte (D-Serine) was done using the linear curve equation $(y=m x+c)$. The concentration was found out to be $0.919 \pm 0.02 \mathrm{nM}$. Further, the validation of the obtained results has been carried out by performing the recovery test. For this, the analyzed sample with the known concentration of D-Serine was spiked with different concentrations of standards i.e., $5 \mathrm{nmol}, 8 \mathrm{nmol}$, and $10 \mathrm{nmol}$. The chromatogram for the spiked sample of D-serine by adding 8 and $10 \mathrm{nM}$ is given in Fig. S2. The obtained results were tabulated in Table 2. The recovery of the spiked samples varies from 85 to $90 \%$. 


\section{Discussion}

Molecular/genetic markers have enormous potential for exploring the emergence and transformations of organic material, but for quantitative applications, it is essential to comprehend the biological sources and diagnostic reactivity of biomarkers. D-AAs are important components of the bacterial cell walls, making them valuable molecular/genetic markers for bacterial-derived organic material in the surrounding environment [14]. In the past few years, shreds of evidence have been reported in the context of the presence of free D-AAs such as D-aspartate and D-serine in prokaryotes and eukaryotes [24].

The present study enumerates the enantiomeric distribution of serine in the bacterial domain. For the same, screening of bacteria that grown well in a medium containing L-serine as a sole nitrogen source was done. The reason for the analysis of these enantiomers was to select the potent microbial strain capable of synthesizing serine racemase (SR). The racemization is the process of converting an optically active compound into a racemic form (containing L\&D forms) and racemases are the biologically active molecules required for the synthesis of diastereomers [40]. D-serine is synthesized from L-serine by PLP dependent serine racemase and is reported to be present in eukaryotes as well as prokaryotes [24]. The growth was observed for up to $48 \mathrm{~h}$ of incubation at $37^{\circ} \mathrm{C}$. The strain $\mathrm{A} 1 \mathrm{C} 1$ isolated from the soil, Solan (H.P) showed maximum growth among all the isolates. The isolated strain grew well at $37 \pm 0.5{ }^{\circ} \mathrm{C}, 150 \mathrm{RPM}, \mathrm{pH} 7 \pm 0.5$, was motile, able to ferment sugar, positive for indole test, and grown on MRS broth medium. In addition, morphologically the strain was Gram-positive, rod-shaped, irregular, whitish, and enlarged colonies able to synthesize spores. Bacillus species are reported to remain in the dormant state for years in the form of endospores and can survive in extreme temperatures, radiations, desiccation, and antibiotic stress. This resistance helps them to survive in a controlled environment for years [41].

Moreover, molecular analysis showed the close relation of $\mathrm{A} 1 \mathrm{C} 1$ to genus Bacillus tequilensis. Hence under all the observations, the isolated strain was named Bacillus tequilensis $\mathrm{A} 1 \mathrm{C} 1$ and submitted in GeneBank (accession no. MZ337537). The Genus Bacillus is a group of Gram-positive, rod-shaped bacteria, obligate aerobes, or facultative anaerobes and falls under the phylum Firmicutes [42]. The optimum growth conditions like temperature and $\mathrm{pH}$ were also reported same for the standard strain Bacillus tequilensis $10 \mathrm{~b}^{\top}$ [43]. Bacillus species are widely distributed in nature such as soil, water, oceans, and can grow in extreme conditions like temperature and pH [44-46]. Bacillus tequilensis GYLH001, a Gram-positive and rod-shaped bacteria isolated from Angelica dahurica released an antifungal agent and was capable to grow in the temperature range of $4-80^{\circ} \mathrm{C}$ (best growth observed at $37^{\circ} \mathrm{C}$ ), $7 \mathrm{pH}$ and 180 RPM. The reported strain is slightly halophilic and was able to grow in media containing $8 \% \mathrm{NaCl}$ concentration. Temperature and $\mathrm{pH}$ greatly affected the production of antifungal agents [29]. Bacillus tequilensis SALBT isolated from soil was reported to produce pectinase and showed optimum growth at $37^{\circ} \mathrm{C}, 7.4 \mathrm{pH}$ at $120 \mathrm{RPM}$. The reported strain was Gram-positive and rod-shaped [30].

A Biosafety test of $\mathrm{A} 1 \mathrm{C} 1$ was also performed on a human blood agar medium to ensure its pathogenicity level. The isolated strain exhibited no zone of RBC hemolysis, indicating that it is not 
harmful to people and may thus be studied further. These results were compatible with the recent study given by Sharifi \& Kunchirman [47].

Bacillus species tend to secrete large quantities of extracellular enzymes and secondary metabolites which place them among the industrially important enzyme producers [48-50]. Bacillus tequilensis strain was reported to secrete proteolytic enzymes [31]. So A1C1 was also tested and found to secrete proteolytic enzymes. The isolated strain was also tested for other industrially important enzymes such as cellulase, chitinase, amylase, and gelatinase. Although, A1C1 had not shown any zone of hydrolysis in cellulose, pectin, and starch medium which stated its inability to secrete these enzymes (Fig 4). Surprisingly, as per the standard strain Bacillus tequilensis $10 \mathrm{~b}^{\top}, \mathrm{A} 1 \mathrm{C} 1$ was also found to secrete gelatine hydrolyzing enzyme [43]. The ability of genus Bacillus to ferment sugar in various $\mathrm{pH}$ ranges, to grow in various temperature ranges has led to extract a variety of $\mathrm{pH}$ and thermally stable enzymes to address numerous applications [48]. The synthesis of secondary metabolites and enzymes also improves host resistance against pathogens by releasing antimicrobial agents [31]. In addition, the Bacillus tequilensis strain was also reported to exhibit PGPR attributes [51]. In our study, we have found no phosphate solubilization index and IAA production by the isolated strain A1C1. This variation in results could be due to the sample collected under various weather conditions which might have affected the bacterial tendency to produce secondary metabolites.

Studies also have shown the antimicrobial potency of Bacillus tequilensis [31, 47, 52]. In our study, the antimicrobial assay performed for the A1C1 showed a zone of inhibition against MTCC 40 $(5 \mathrm{~mm})$ and MTCC 11949 (2mm). It was found that the extracellular fraction was more potent against Gram-positive and negative strains than the intracellular fraction which may be due to the secretion of extracellular enzymes and other secondary metabolites. The pure cultures of MTCC 40 (Escherichia coli) and MTCC 11949 (Staphylococcus aureus) were procured from MTCC, Chandigarh, and preserved at $4^{\circ} \mathrm{C}$ before the test. Escherichia coli is a Gram-negative, facultatively anaerobic, and coliform bacteria commonly found in the human gut microbiome. The pathogenic strain of Escherichia coli has been reported to cause urinary tract infection and food poisoning [53]. Whereas, Staphylococcus aureus is a Gram-positive bacterium involved in food poisoning and skin infection [54]. At the present number of lethal microbes have acquired many ways to surpass the antibacterial agent [55] which critically demands new approaches to get resolved. Till now many Bacillus strains such as Bacillus subtilis, Bacillus polymyxa, Bacillus brevis, Bacillus licheniformis, Bacillus circulans, and Bacillus cereus have been reported to produce antibiotics [56]. In another study of the same bacillus species, the purified extract was found potent against Staphylococcus aureus (15mm) [52] and Escherichia coli (10mm) [47]. Curiously, this study has added a valuable finding and a step toward the development of biologically active peptides from the Bacillus tequilensis strain. Purified bacterial extract and peptides may enhance its antibacterial activity and can be tested against several pathogenic strains.

The presence of D-AAs in bacterial cultures validates previous findings that these biomolecules are found in a wide range of macromolecules. Aside from peptidoglycan, other potential DAA sources include lipopolysaccharides, polypeptides, lipopeptides, and siderophores, all of which are 
components of the bacterial cell wall-membrane complex [14]. It is required to precisely measure trace amounts of $D$ enantiomers in the presence of a significant excess of $L$ enantiomers to identify and quantify D-AAs in tissues. As a result, the analyses of D-serine were performed at low concentrations in the presence of a $5 \mathrm{nM}$ pure standard. The detection limit was set at 5-30 nM. When a biological component is analyzed in the presence of additional components, an incorrect determination is probable if the study is conducted using a single technique. The current approach appears to reduce this concern since it combines two techniques, TLC and RP-HPLC. At first, bacterial fractions were subjected to TLC for the separation of amino acids. Before separation, TLC developing chamber was saturated by placing Whatman filter paper-1 (wetted with eluent and lining on the wall of the chamber) to improve the separation and reproducibility [57]. Then the extracted amino acids were derivatized with OPA/IBLC for further separation and quantification by HPLC. A known amount (nmol) of standard (D-serine) was derivatized with OPA/IBLC and used for the quantification of D-serine which was present in the bacterial fraction i.e., $0.919 \pm 0.02 \mathrm{nM}$. Several other bacterial strains were also explored and assayed for the traces of serine enantiomers [13-16]. In our study, D-serine was detected in the intracellular fraction of the cultivated cells of $\mathrm{A} 1 \mathrm{C} 1$ (Fig 8b). D-serine is commonly present in the bacterial cell wall, lipopeptides, and siderophores, although it may also exist as a free molecule [14, 58-60]. Gram-positive bacteria have a thicker cell wall than Gram-negative bacteria and due to this fact, D-Serine is not the component of Gramnegative bacteria's peptidoglycan and is found to be present in bacterial macromolecules [14]. Further, we were unable to detect $D$-serine in the culture media, which stated that $A 1 C 1$ could not secrete $D$-serine extracellularly. Further, studies are needed to determine the synthesis and physiological role of $D$-serine in the isolated culture strain Bacillus tequilensis A1C1.

\section{Declarations}

Funding The work was supported in terms of lab facilities (instruments and chemicals) by Chandigarh University, Gharuan.

Conflict of interest The authors declare no conflict of interest either financially or non-financially.

Availability of data and material The data set analyzed and generated during this study is only available from the corresponding author on reasonable request.

\section{Code availability Not applicable}

Ethics approval Human blood agar was used to assess the biosafety of the bacterial isolate. Self-blood $(2.5 \mathrm{ml})$ was utilized for preparation under the supervision of a medical practitioner. All procedures were carried out per the Departmental Research Committee's ethical guidelines as well as the 1964 Helsinki Declaration and its subsequent revisions or similar ethical standards.

Consent to participate Not applicable

Consent for publication Not applicable 
Author's contributions The research proposal was designed by VS and TK. Experimental work and paper writing was done by SK. Chromatographic interpretations were done by MB. Further, the final manuscript editing and corrections were followed by VS.

\section{References}

1. Hashimoto A, Nishikawa T, Hayashi T, et al (1992) The presence of free D-serine in rat brain. FEBS Lett 296:33-36.

2. Huang $\mathrm{Y}$, Nishikawa T, Satoh $\mathrm{K}$, et al (1998) Urinary excretion of D-serine in human: comparison of different ages and species. Biol Pharm Bull 21:156-162.

3. Boehning D, Snyder SH (2003) Novel neural modulators. Annu Rev Neurosci 26:105-131.

4. Wolosker H, Dumin E, Balan L, Foltyn VN (2008) D-amino acids in the brain: D-serine in neurotransmission and neurodegeneration. FEBS J 275:3514-3526.

5. Papouin T, Ladépêche L, Ruel J, et al (2012) Synaptic and extrasynaptic NMDA receptors are gated by different endogenous coagonists. Cell 150:633-646.

6. Rosenberg D, Artoul S, Segal AC, et al (2013) Neuronal D-serine and glycine release via the Asc-1 transporter regulates NMDA receptor-dependent synaptic activity. J Neurosci 33:3533-3544.

7. Panatier A, Theodosis DT, Mothet J-P, et al (2006) Glia-derived D-serine controls NMDA receptor activity and synaptic memory. Cell 125:775-784.

8. Katsuki H, Nonaka M, Shirakawa $\mathrm{H}$, et al (2004) Endogenous D-serine is involved in induction of neuronal death by $\mathrm{N}$-methyl-D-aspartate and simulated ischemia in rat cerebrocortical slices. $\mathrm{J}$ Pharmacol Exp Ther 311:836-844.

9. Michard E, Lima PT, Borges F, et al (2011) Glutamate receptor-like genes form Ca2+ channels in pollen tubes and are regulated by pistil D-serine. Science 332:434-437.

10. Pollock GE, Cheng CN, Cronin SE (1977) Determination of the D and L isomers of some protein amino acids present in soils. Anal Chem 49:2-7.

11. Dittmar T, Fitznar HP, Kattner G (2001) Origin and biogeochemical cycling of organic nitrogen in the eastern Arctic Ocean as evident from D-and L-amino acids. Geochim Cosmochim Acta 65:41034114.

12. Kawasaki N, Benner R (2006) Bacterial release of dissolved organic matter during cell growth and decline: molecular origin and composition. Limnol Oceanogr 51:2170-2180. 
13. Arias CA, Martín-Martinez M, Blundell TL, et al (1999) Characterization and modelling of VanT: a novel, membrane-bound, serine racemase from vancomycin-resistant Enterococcus gallinarum BM4174. Mol Microbiol 31:1653-1664.

14. Kaiser K, Benner R (2008) Major bacterial contribution to the ocean reservoir of detrital organic carbon and nitrogen. Limnol Oceanogr 53:99-112.

15. Nagata $Y$, Tanaka K, lida T, et al (1999) Occurrence of D-amino acids in a few archaea and dehydrogenase activities in hyperthermophile Pyrobaculum islandicum. Biochim Biophys Acta, Prot Struct Mol Enzymol 1435:160-166.

16. Nagata Y, Fukuda A, Sakai M, et al (2001) D-amino acid contents of mitochondria and some purple bacteria. J Mol Catal B Enzym 12:109-113.

17. Kapil S, Sharma V (2021) d-Amino acids in antimicrobial peptides: a potential approach to treat and combat antimicrobial resistance. Can J Microbiol 67:119-137.

18. Martinez JS, Zhang GP, Holt PD, et al (2000) Self-assembling amphiphilic siderophores from marine bacteria. Science 287:1245-1247.

19. Pradhan AK, Pradhan N, Mall G, et al (2013) Application of lipopeptide biosurfactant isolated from a halophile: Bacillus tequilensis $\mathrm{CH}$ for inhibition of biofilm. Appl Biochem Biotechnol 171:13621375.

20. Vater J, Kablitz B, Wilde C, et al (2002) Matrix-assisted laser desorption ionization-time of flight mass spectrometry of lipopeptide biosurfactants in whole cells and culture filtrates of Bacillus subtilis C1 isolated from petroleum sludge. Appl Environ Microbiol 68:6210.

21. Healy VL, Park I-S, Walsh CT (1998) Active-site mutants of the VanC2 D-alanyl-D-serine ligase, characteristic of one vancomycin-resistant bacterial phenotype, revert towards wild-type D-alanyl-Dalanine ligases. Chem Biol 5:197-207.

22. Wolosker H, Blackshaw S, Snyder SH (1999) Serine racemase: a glial enzyme synthesizing Dserine to regulate glutamate-N-methyl-D-aspartate neurotransmission. Proc Natl Acad Sci 96:1340913414.

23. de Miranda J, Panizzutti R, Foltyn VN, Wolosker H (2002) Cofactors of serine racemase that physiologically stimulate the synthesis of the N-methyl-D-aspartate (NMDA) receptor coagonist D-serine. Proc Natl Acad Sci 99:14542-14547.

24. KAPIL S, SHARMA V (2020) SERINE RACEMASES FROM PROKARYOTES TO EUKARYOTES: AN OVERVIEW ON ITS ROLE AND EXISTENCE. Plant Cell Biotechnol Mol Biol 17-28. 
25. Kubota T, Shimamura S, Kobayashi T, et al (2016) Distribution of eukaryotic serine racemases in the bacterial domain and characterization of a representative protein in Roseobacter litoralis Och 149. Microbiology 162:53-61.

26. Schleifer KH, Kandler O (1972) Peptidoglycan types of bacterial cell walls and their taxonomic implications. Bacteriol Rev 36:407.

27. Pradhan AK, Rath A, Pradhan N, et al (2018) Cyclic lipopeptide biosurfactant from Bacillus tequilensis exhibits multifarious activity. 3 Biotech 8:1-7.

28. Velusamy P, Pachaiappan R, Christopher M, et al (2015) Isolation and identification of a novel fibrinolytic Bacillus tequilensis CWD-67 from dumping soils enriched with poultry wastes. J Gen Appl Microbiol 61:241-247.

29. Li H, Guan Y, Dong Y, et al (2018) Isolation and evaluation of endophytic Bacillus tequilensis GYLH001 with potential application for biological control of Magnaporthe oryzae. PLoS One 13:e0203505.

30. Koshy M, De S (2019) Effect of Bacillus tequilensis SALBT crude extract with pectinase activity on demucilation of coffee beans and juice clarification. J Basic Microbiol 59:1185-1194.

31. Khan Z, Shafique M, Nawaz HR, et al (2019) Bacillus tequilensis ZMS-2: A novel source of alkaline protease with antimicrobial, anti-coagulant, fibrinolytic and dehairing potentials. PJPS 32:191318.

32. Bergey DH (2001) Bergey's Manual ${ }^{\circledR}$ of Systematic Bacteriology. Springer Science \& Business Media

33. Altschul SF, Gish W, Miller W, et al (1990) Basic local alignment search tool. J Mol Biol 215:403410.

34. Agrawal T, Kotasthane AS (2012) Chitinolytic assay of indigenous Trichoderma isolates collected from different geographical locations of Chhattisgarh in Central India. SpringerPlus 1:1-10.

35. Gopalakrishnan S, Pande S, Sharma M, et al (2011) Evaluation of actinomycete isolates obtained from herbal vermicompost for the biological control of Fusarium wilt of chickpea. Crop Prot 30:1070-1078.

36. Bose A, Chawdhary V, Keharia H, Subramanian RB (2014) Production and characterization of a solvent-tolerant protease from a novel marine isolate Bacillus tequilensis P15. Ann Microbiol 64:343354.

37. Valgas C, Souza SM de, Smânia EF, Smânia Jr A (2007) Screening methods to determine antibacterial activity of natural products. Braz J Microbiol 38:369-380. 
38. Kaiser K, Benner R (2000) Determination of amino sugars in environmental samples with high salt content by high-performance anion-exchange chromatography and pulsed amperometric detection. Anal Chem 72:2566-2572.

39. Kaiser K, Benner R (2005) Hydrolysis-induced racemization of amino acids. Limnol OceanogrMeth 3:318-325.

40. Tanner ME (2002) Understanding nature's strategies for enzyme-catalyzed racemization and epimerization. Acc Chem Res 35:237-246.

41. Christie G, Setlow P (2020) Bacillus spore germination: Knowns, unknowns and what we need to learn. Cell Signal 109729.

42. Turnbull PCB (1996) Bacillus: Barron's medical microbiology. University of Texas Medical Branch

43. Gatson JW, Benz BF, Chandrasekaran C, et al (2006) Bacillus tequilensis sp. nov., isolated from a 2000-year-old Mexican shaft-tomb, is closely related to Bacillus subtilis. Int J Syst Evol Microbiol $56: 1475-1484$.

44. Nazina TN, Lebedeva EV, Poltaraus AB, et al (2004) Geobacillus gargensis sp. nov., a novel thermophile from a hot spring, and the reclassification of Bacillus vulcani as Geobacillus vulcani comb. nov. Int J Syst Evol Microbiol 54:2019-2024.

45. Slonczewski JL, Foster JW (2013) Microbiology: An evolving science: Third international student edition. WW Norton \& Company.

46. Wijnands LM, Dufrenne JB, Zwietering MH, Van Leusden FM (2006) Spores from mesophilic Bacillus cereus strains germinate better and grow faster in simulated gastro-intestinal conditions than spores from psychrotrophic strains. Int J Food Microbiol 112:120-128.

47. Sharifi M, kunchirman BN (2020) Isolation and Identification of Bacillus Tequilensis from Mangrove Soil and Their Antimicrobial Activity against Common Pathogens. IJSRP 11:326-330.

48. Schallmey M, Singh A, Ward OP (2004) Developments in the use of Bacillus species for industrial production. Can J Microbiol 50:1-17.

49. Zhao L, Li X, Wang Z, et al (2019) A new strain of Bacillus tequilensis CGMCC 17603 isolated from biological soil crusts: A promising sand-fixation agent for desertification control. Sustainability 11:6501.

50. Wagh SK, Gadge PP, Padul MV (2018) Significant Hydrolysis of Wheat Gliadin by Bacillus tequilensis (10bT/HQ223107): a Pilot Study. Probiotics Antimicrob 10:662-667. 
51. Mukherjee B, Dutta S (2019) Isolation of a phosphate solubilizing bacterial strain bacillus Tequilensis mcc 3872 from the rice field of burdwan district and characterization of its plant growth promoting traits. Pharm Innov J 8: 956-962.

52. Kaur G, Tewari R, Soni SK (2018) Screening of Secondary Metabolites for Antimicrobial Applications from Bacillus tequilensis RG2 (SOIL ISOLATE). J Pharm Innov 8:372-379.

53. Braden CR (2017) Emerging and Zoonotic Infectious Diseases.

54. Kuroda M, Ohta T, Uchiyama I, et al (2001) Whole genome sequencing of meticillin-resistant Staphylococcus aureus. The Lancet 357:1225-1240.

55. Kapil S, Kumar T, Sharma V Mechanism and challenges associated with adaptation and evolution of drug-resistant bacteria: an overview. As Pac J Mol Biol Biotechnol 28:1-18.

56. Yilmaz M, Soran H, Beyatli Y (2006) Antimicrobial activities of some Bacillus spp. strains isolated from the soil. Microbiol Res 161:127-131.

57. Geiss F (1987) Fundamentals of thin layer chromatography.

58. Bernardini J-J, Linget-Morice C, Hoh F, et al (1996) Bacterial siderophores: structure elucidation, and $1 \mathrm{H}, 13 \mathrm{C}$ and $15 \mathrm{~N}$ two-dimensional NMR assignments of azoverdin and related siderophores synthesized by Azomonas macrocytogenes ATCC 12334. Biometals 9:107-120.

59. Demange P, Bateman A, Mertz C, et al (1990) Bacterial siderophores: structures of pyoverdins Pt, siderophores of Pseudomonas tolaasii NCPPB 2192, and pyoverdins Pf, siderophores of Pseudomonas fluorescens CCM 2798. Identification of an unusual natural amino acid. Biochemistry 29:11041-11051.

60. Morikawa M, Daido H, Takao T, et al (1993) A new lipopeptide biosurfactant produced by Arthrobacter sp. strain MIS38. J Bacteriol 175:6459-6466.

\section{Tables}




\begin{tabular}{|c|c|c|c|c|}
\hline Test & A1C1 & $\begin{array}{l}\text { Bacillus } \\
\text { tequilensis SALBT }\end{array}$ & $\begin{array}{l}\text { Bacillus } \\
\text { tequilensis GYLH001 }\end{array}$ & $\begin{array}{l}\text { Bacillus } \\
\text { tequilensis } 10 \mathrm{~b}^{\mathrm{T}}\end{array}$ \\
\hline Shape & Rod & Rod & Rod & Rod \\
\hline Gram-staining & + & + & + & + \\
\hline Catalase activity & - & + & ND & + \\
\hline Triple sugar iron & $\begin{array}{c}+\begin{array}{c}\text { no black ppt } \\
\text { observed }\end{array} \\
\text { obsed }\end{array}$ & ND & ND & ND \\
\hline $\begin{array}{l}\text { Lactose } \\
\text { fermentation }\end{array}$ & + & ND & ND & + \\
\hline Indole & + & - & - & + \\
\hline MR-VP & - & - & + & ND \\
\hline $\begin{array}{l}\text { Citrate } \\
\text { utilization }\end{array}$ & - & - & + & + \\
\hline MRS broth & + & ND & ND & ND \\
\hline Urease & - & + & ND & ND \\
\hline $\begin{array}{l}\text { Starch } \\
\text { hydrolysis }\end{array}$ & - & + & + & + \\
\hline $\begin{array}{l}\text { Casein } \\
\text { hydrolysis }\end{array}$ & + & + & + & ND \\
\hline $\begin{array}{l}\text { Cellulose } \\
\text { hydrolysis }\end{array}$ & - & + & + & ND \\
\hline Gelatinase & + & ND & + & + \\
\hline Motility & + & $\mathrm{ND}$ & + & + \\
\hline $\begin{array}{l}\text { Temperature } \\
\text { range }\end{array}$ & $20-50^{\circ} \mathrm{C}, 37^{\circ} \mathrm{C}^{*}$ & $37^{\circ} \mathrm{C} *$ & $4-80^{\circ} \mathrm{C}, 37^{\circ} \mathrm{C}^{*}$ & $20-50^{\circ} \mathrm{C}, 40-50^{\circ} \mathrm{C}^{*}$ \\
\hline pH range & $5-9,7 *$ & $7.4^{*}$ & $1-9,7 *$ & $5.5-8,6.5-8 *$ \\
\hline RPM & 150* & $120 *$ & $180 *$ & ND \\
\hline
\end{tabular}

ND, not determined; +, positive utilization; -, negative utilization; *, optimum growth.

\begin{tabular}{|c|c|c|c|c|}
\hline Sr. No. & Sample & Sample ID & Conc. (nM) & Recovery (\%) \\
\hline 1. & Unknown (S1 spiked with 5 nM) & $\mathrm{S} 2$ & 5.14759 & 86.79127 \\
\hline 1. & Unknown (S1 spiked with 8 nM) & S3 & 7.902014 & 88.47849 \\
\hline 1. & Unknown (S1 spiked with 10 nM) & $\mathrm{S} 4$ & 9.728746 & 89.00143 \\
\hline
\end{tabular}

\section{Figures}




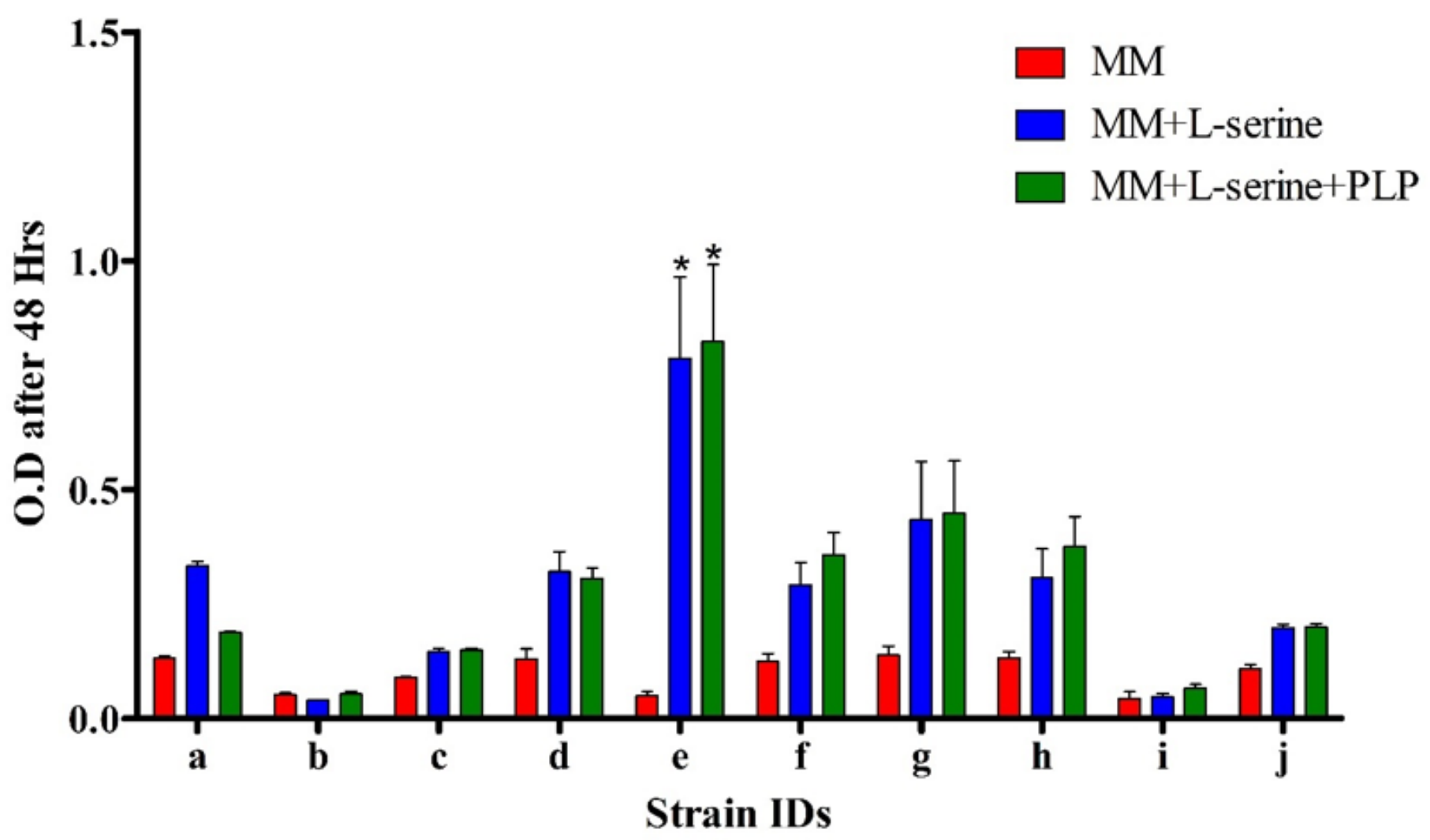

Figure 1

Growth of isolates observed after $48 \mathrm{~h}$ of incubation. MM- Minimal essential media, L-serine- Minimal essential media supplemented with L-serine, L-serine+PLP- Minimal essential media supplemented with L-serine and PLP. Error bars represent the Mean \pm SD of three independent values $(n=3)$. 


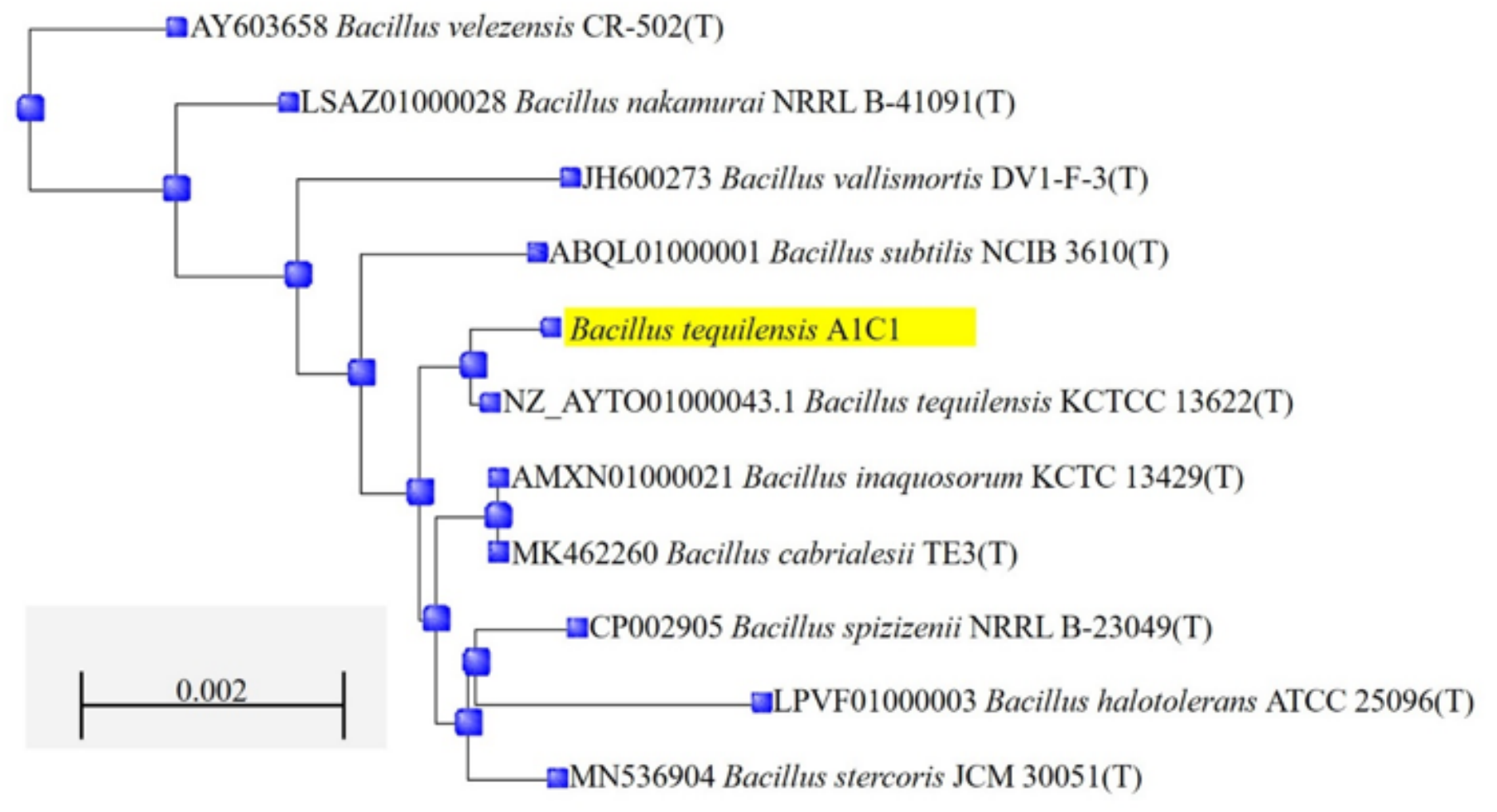

Figure 2

Phylogenetic tree construction of Bacillus tequilensis A1C1 analogs using Maximum Likelihood method by employing Neighbor-Joining method. 


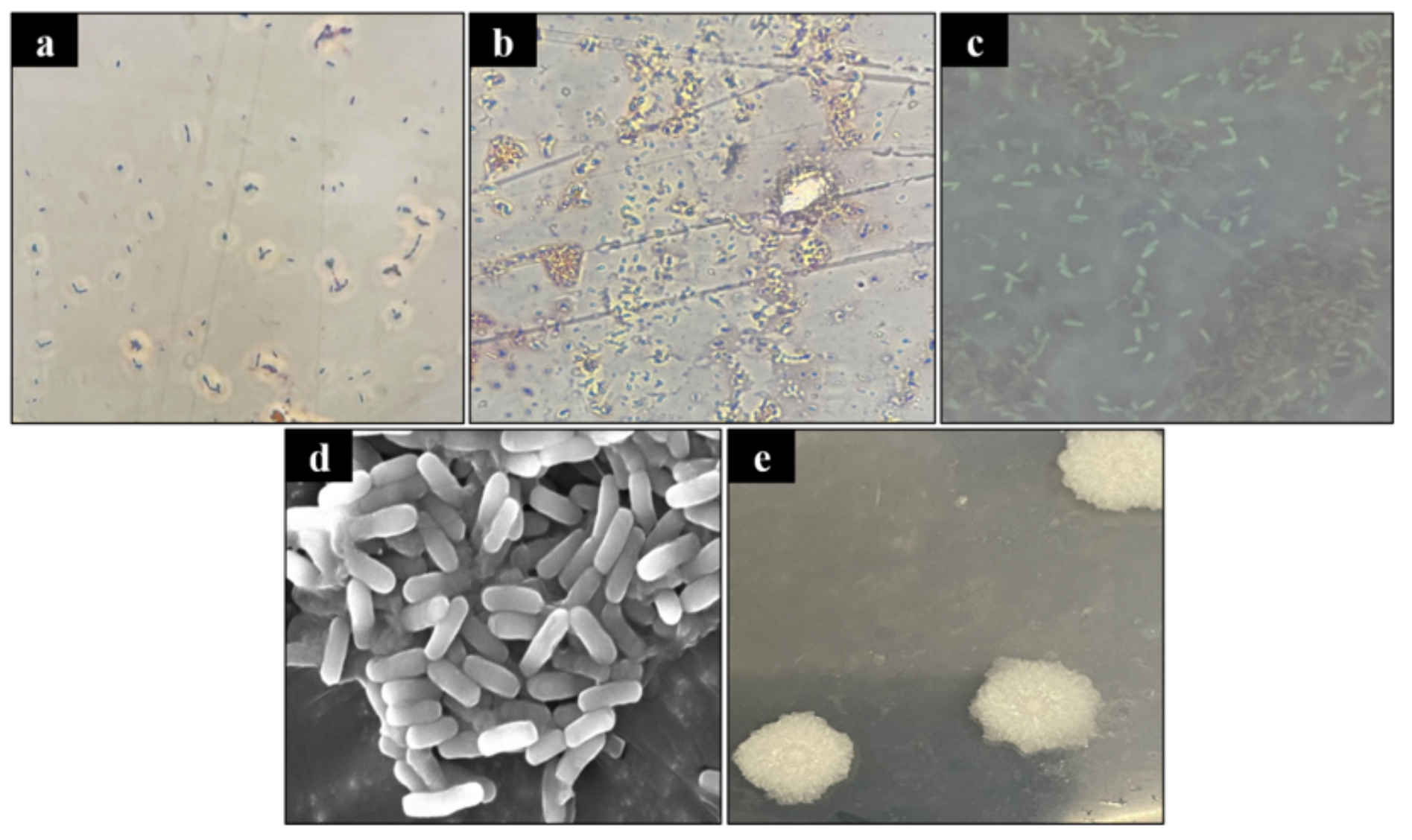

Figure 3

The morphological features of A1C1. a Gram staining. b Spore staining. c Observation at 100X. d SEM observation. e Colony morphology. 

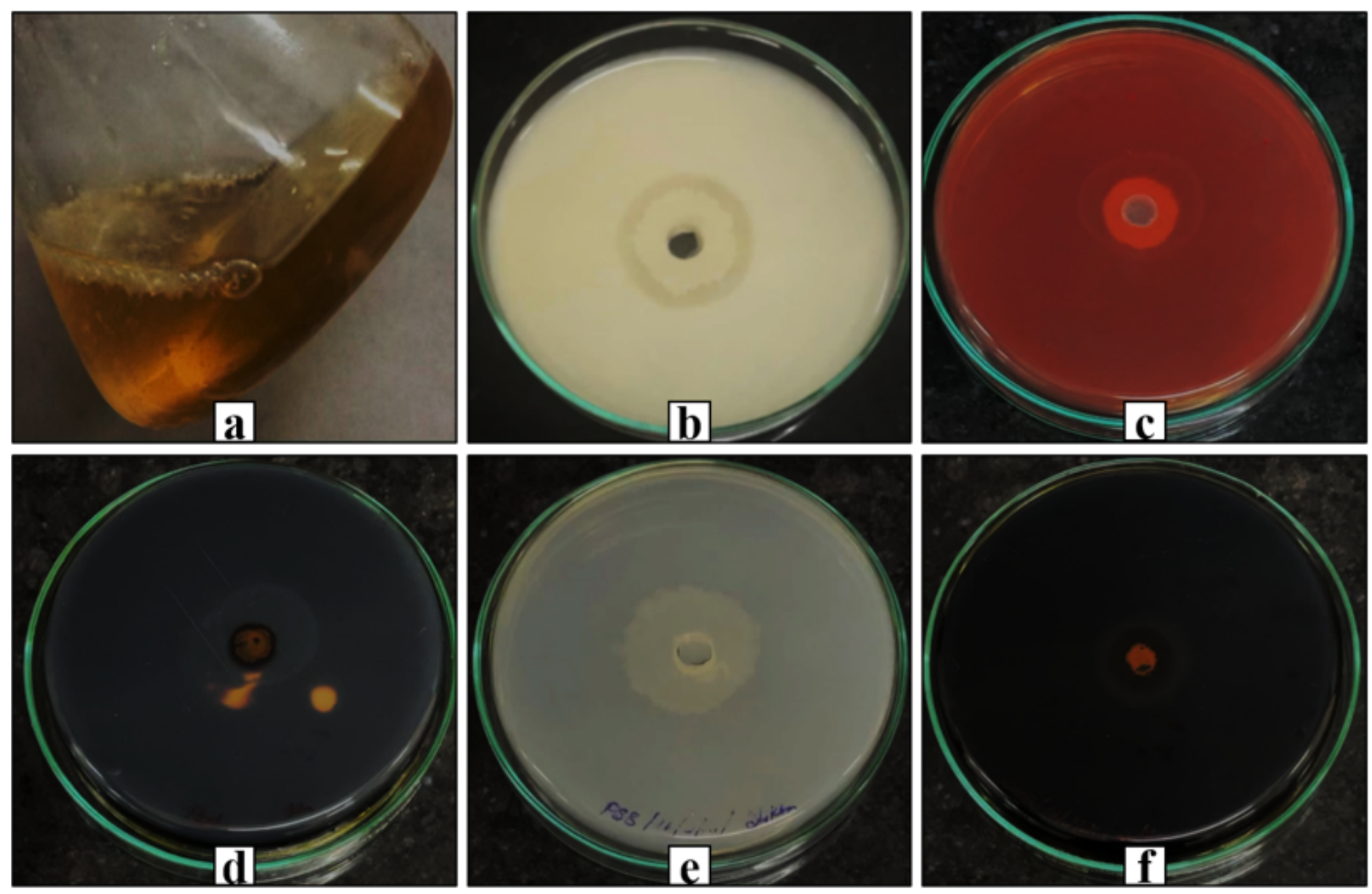

\begin{tabular}{|l|l|}
\hline Production & A1C1 \\
\hline Gelatinase & + \\
\hline Protease & + \\
\hline Cellulase & - \\
\hline Pectinase & - \\
\hline Amylase & - \\
\hline Phosphate solubilization & - \\
\hline IAA & - \\
\hline
\end{tabular}

\section{Figure 4}

Production of enzymes by A1C1. a Gelatine hydrolysis. b Casein hydrolysis. c Cellulose hydrolysis. d Pectin hydrolysis. e Phosphate solubilization. f Starch hydrolysis. 't', Positive utilization, '-', Negative utilization. 

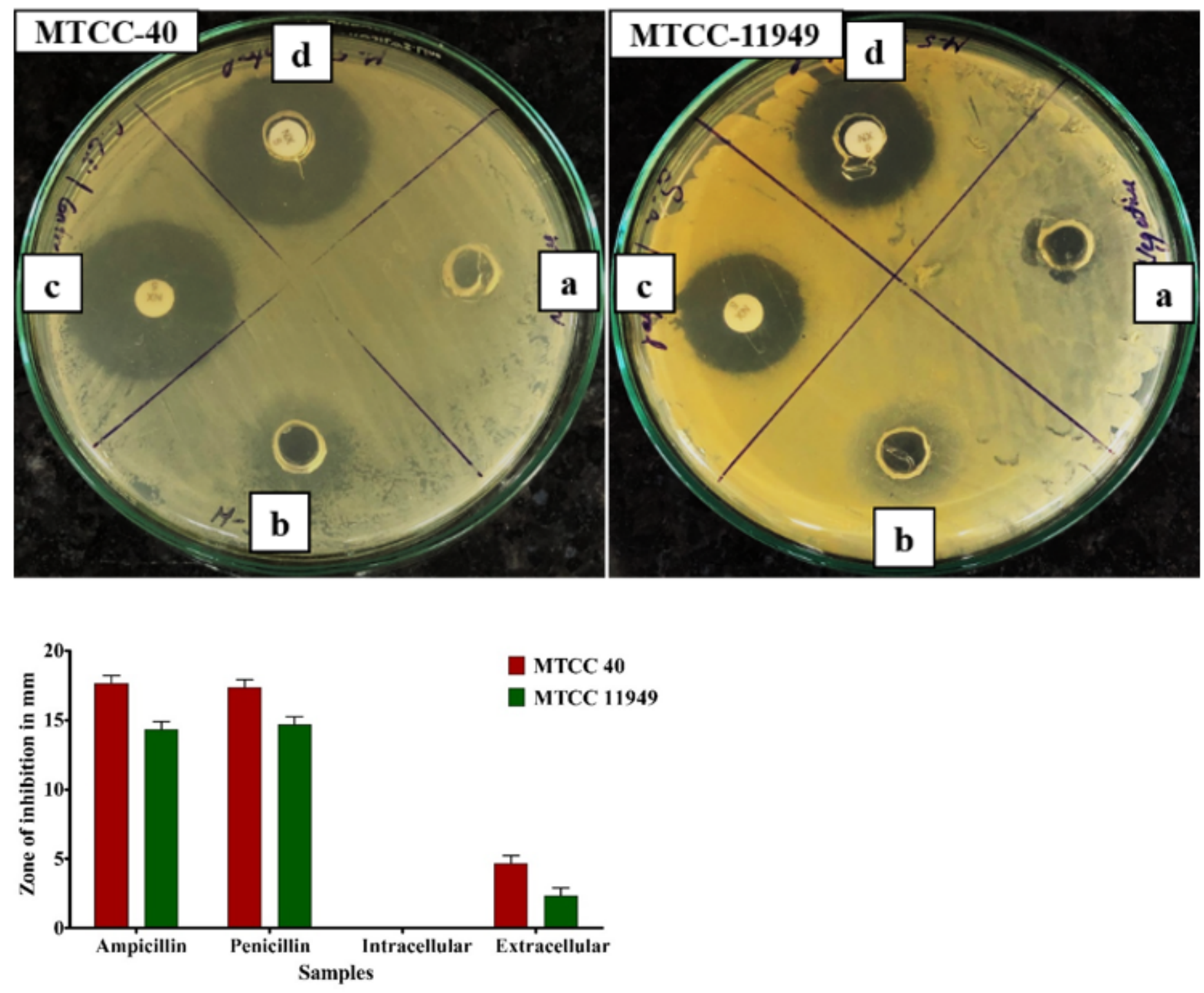

Figure 5

Antimicrobial activity of Intracellular and extracellular fractions with standard drugs. a Intracellular fraction, b Extracellular fraction, c Ampicillin $(10 \mathrm{mcg})$, d Penicillin $(10 \mathrm{mcg})$. Error bars represent Mean \pm S.D of three independent values. 


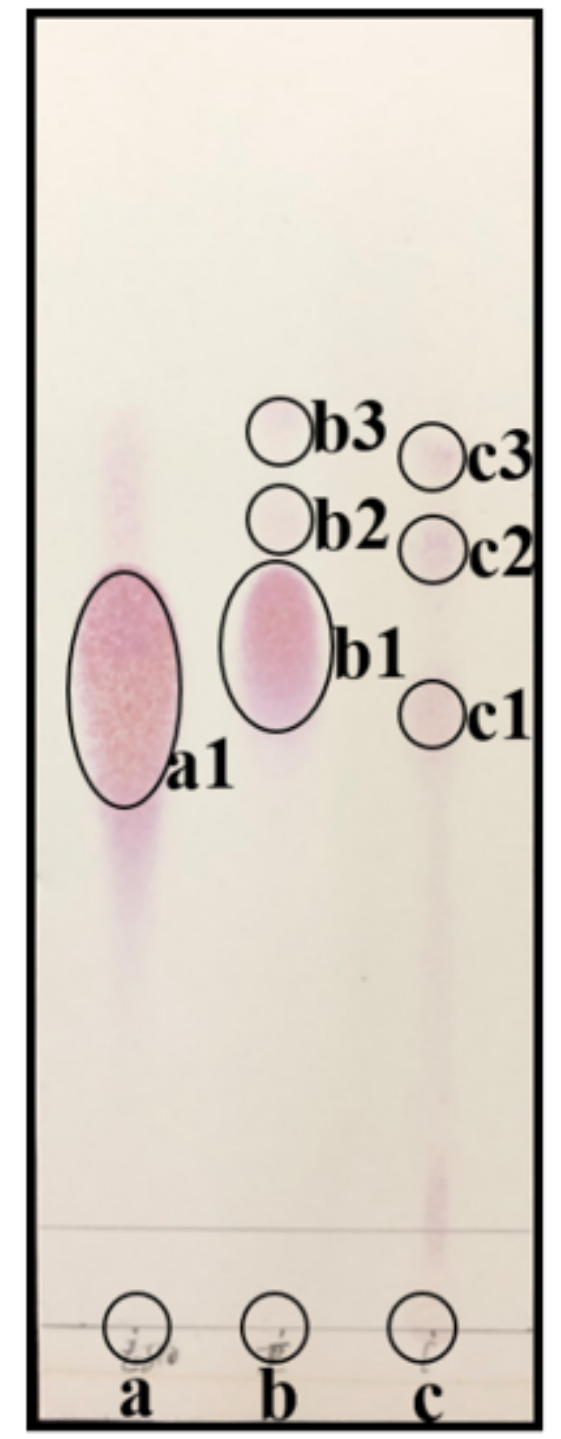

\begin{tabular}{|c|c|}
\hline Sample & RF \\
\hline a1 & $0.51667 \pm 0.015$ \\
\hline b1 & $0.55333 \pm 0.005$ \\
\hline b2 & $0.62 \pm 0.01$ \\
\hline b3 & $0.73 \pm 0.017$ \\
\hline c1 & $0.48667 \pm 0.015$ \\
\hline c2 & $0.62333 \pm 0.005$ \\
\hline c3 & $0.65667 \pm 0.011$ \\
\hline
\end{tabular}

Figure 6

Chromatographic bands obtained after the separation of amino acids on TLC. a L-serine. $b$ Intracellular fraction. c Extracellular fraction. Values are Mean \pm S.D of three independent values $(n=3)$. 
a

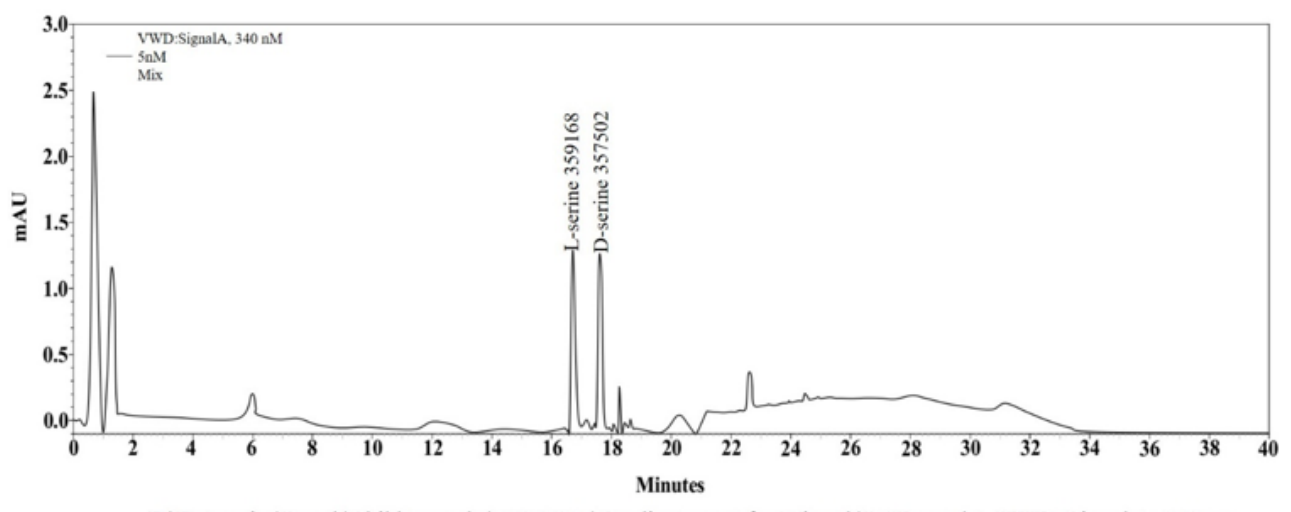

_E: Enterprise Result $\backslash$ Shikha results $\backslash 15072021 \backslash$ Gradient run 4 for Mix.rslt $\lfloor \& D$ ser.dat, VWD: Signal A, $340 \mathrm{~nm}$

b

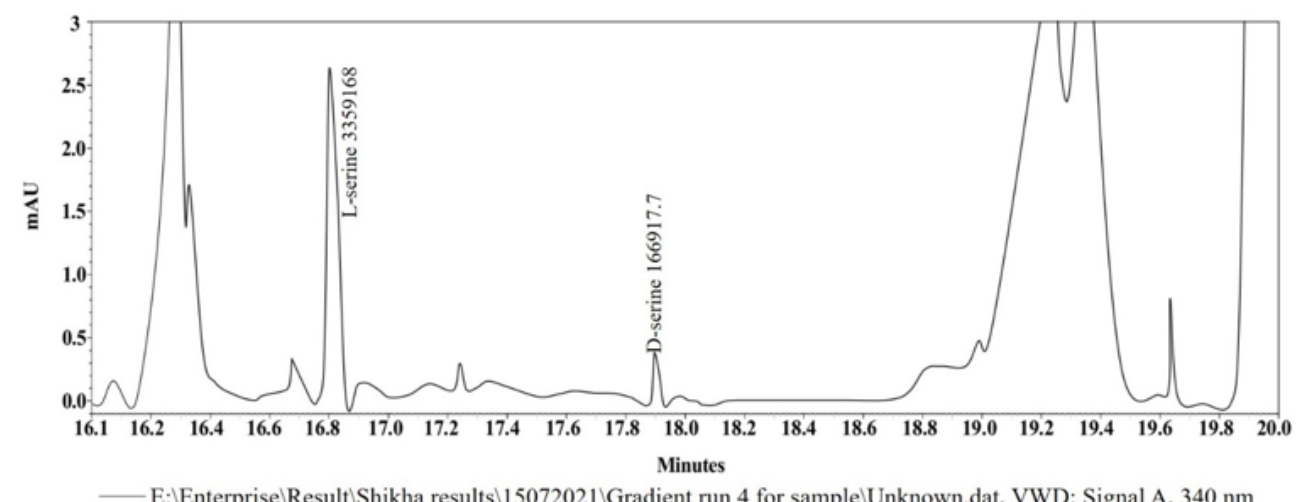

c

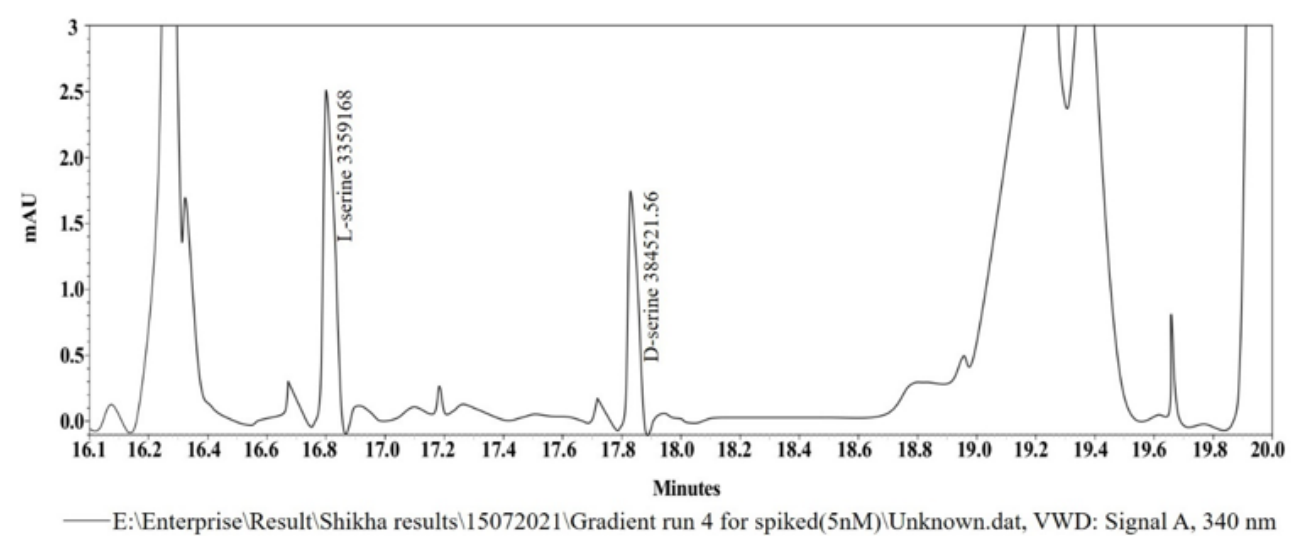

\section{Figure 7}

Elution profile of amino acid composition in the hydrolysate of Bacillus tequilensis A1C1 strain after $20 \mathrm{~h}$ of acid hydrolysis. a $5 \mu$ l of pure L\&D-serine $(5 \mathrm{nM})$ was used as standard. b $5 \mu$ l sample of bacterial hydrolysate. c $5 \mu \mathrm{l}$ sample of bacterial hydrolysate spiked with $5 \mu \mathrm{l}$ of $5 \mathrm{nM} D$-serine. 


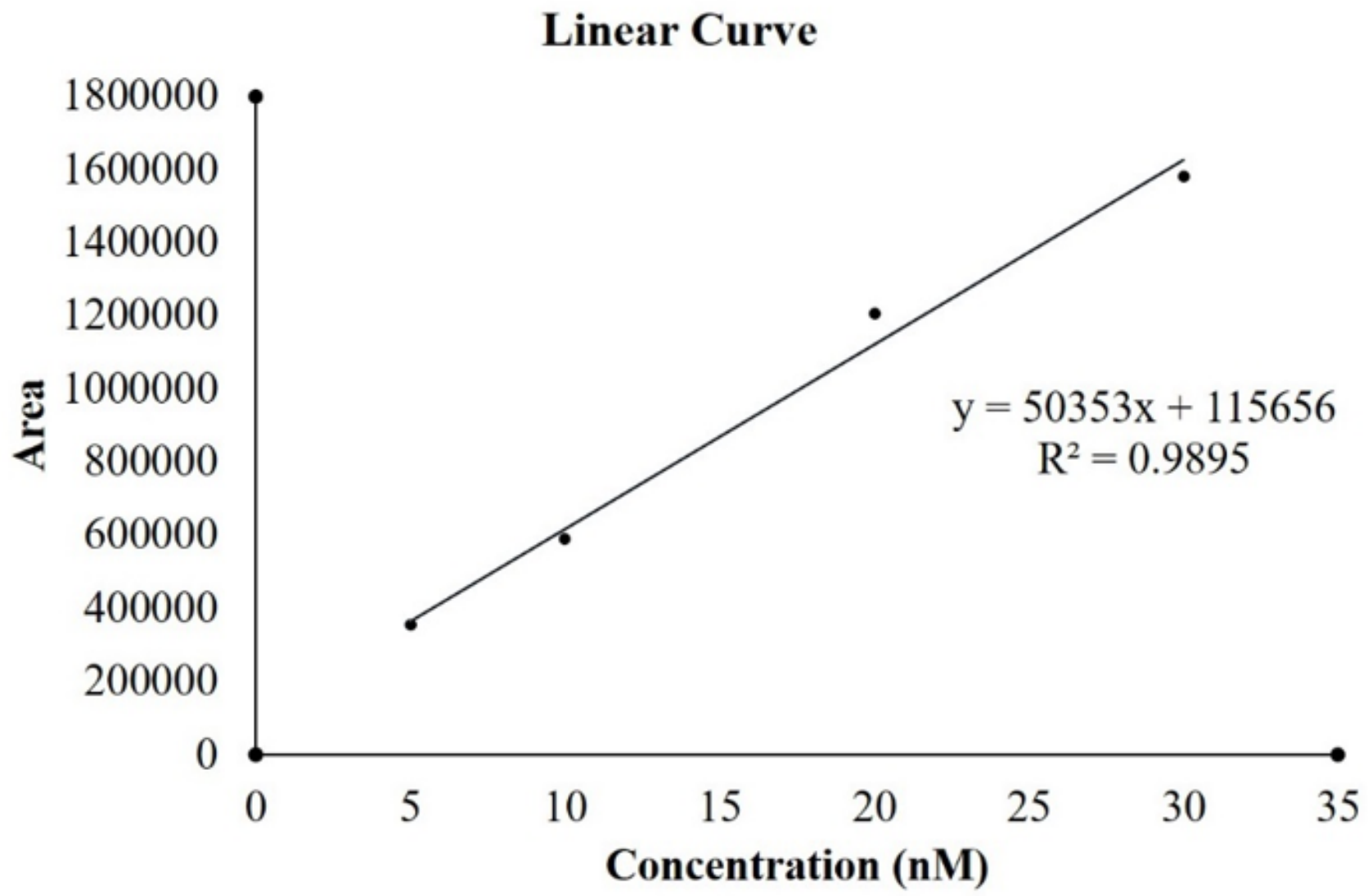

Figure 8

Linear curve drawn by using known concentrations of the standard D-serine.

\section{Supplementary Files}

This is a list of supplementary files associated with this preprint. Click to download.

- Supp.pdf 